\title{
Occurrence of Pseudolarix (Pinaceae) from the Miocene Duho Formation of the Yeonil Group in the Pohang Basin, Korea
}

\author{
Jong-Heon Kim* \\ Department of Earth Science Education, Kongju National University, Chungnam 314-701, Korea
}

\begin{abstract}
Three species of Pseudolarix including P. japonica, P. sp. A, and P. sp. B, all belonging to Pinaceae, are systematically described from the Middle Miocene Duho Formation of the Yeonil Group based on the detached seminiferous scales. The presence of Pseudolarix in the Yeonil flora indicates that various kinds of Pinaceae did flourish during the Middle Miocene. The occurrence of Pseudolarix is the first record in the Korean Tertiary flora.
\end{abstract}

Keywords: Pseudolarix japonica, Middle Miocene, Yeonil Group, seminiferous scales

\section{Introduction}

The Yeonil Group of marine origin is sporadically exposed in the Pohang, Yonghae, and Pukpyong areas in South Korea. Among them, the Yeonil Group of Pohang area has been known to yield abundant macrofossils such as plant fossils, vertebrate, and invertebrate fossils (Kanehara, 1936; Kim and Yoon, 1978; Yoon, 1976a, b; Yoon and Rhee, 1982). The plant and wood fossils from the Yeonil Group of Pohang area were described by previous authors (Kryshtofovich, 1921; Huzioka, 1943, 1972; Tanai, 1952, 1983; Lee, 1975; Chun, 1982; Jeong et al., 2003, 2004; Kim, 2005). The most recent paleobotanical works for the plant fossils in Pohang area were made by Kim and Choi (2008) and Kim (2008, 2009a, b).

Recently 12 seminiferous scales were collected together with many other fossil plants from the Duho Formation of the Yeonil Group distributed along the northern beach of Pohang-City. Although an organic connection between the present seminiferous scales and cone has not been found, the seminiferous scales mentioned above definitively belong to Pseudolarix of Pinaceae. In the Yeonil flora, the fossil records of Pinaceae are very rare and hitherto 2 genera and 4

*Corresponding author: jongheon@kongju.ac.kr Tel: $82-41-850-8295$

Fax: 82-41-850-8299 species, Pinus miocenica, P. sp., Keteleeria ezoana, and $K$. sp. were reported from the Yeonil Group. They are represented by detached foliages or winged seeds.

This paper deals with the description of three species of Pseudolarix first found in the Korean Tertiary flora, based on the seminiferous scales, This study will provide new evidence for biogeographic and climatic relationships.

\section{Geological Setting and Fossil Locality}

Tateiwa (1924) first surveyed the geological investigation on the Tertiary deposits of Pohang Basin and divided them into three series such as the Janggi, Beomgogni, and Yeonil Series in ascending order. Since then, geological and paleontological studies have been carried out by many authors (e.g. Um et al., 1964; Kim, 1965; Yoon, 1975, 1976, 1982, 1992; Lee, 1986; Yun, 1986, 1994; Lee et al., 1988; Chung and Choi, 1993). Further paleontological researches on flora, fauna, and microfossils were made by Tateiwa (1976), Lee (1987), Lim et al. (1994), Kim (1997), Yoon and Yun (2001), and Lee et al. (2004).

According to Kim (1987), the Tertiary deposits of the Pohang Basin are divided into the Yangbuk and Yeonil Groups in ascending order. The former is nearly equivalent to the Changgi Series of Tateiwa (1924). Kim and Choi (2008) already mentioned that the stratigraphic divisions of the Yeonil Group in the Pohang Basin, 


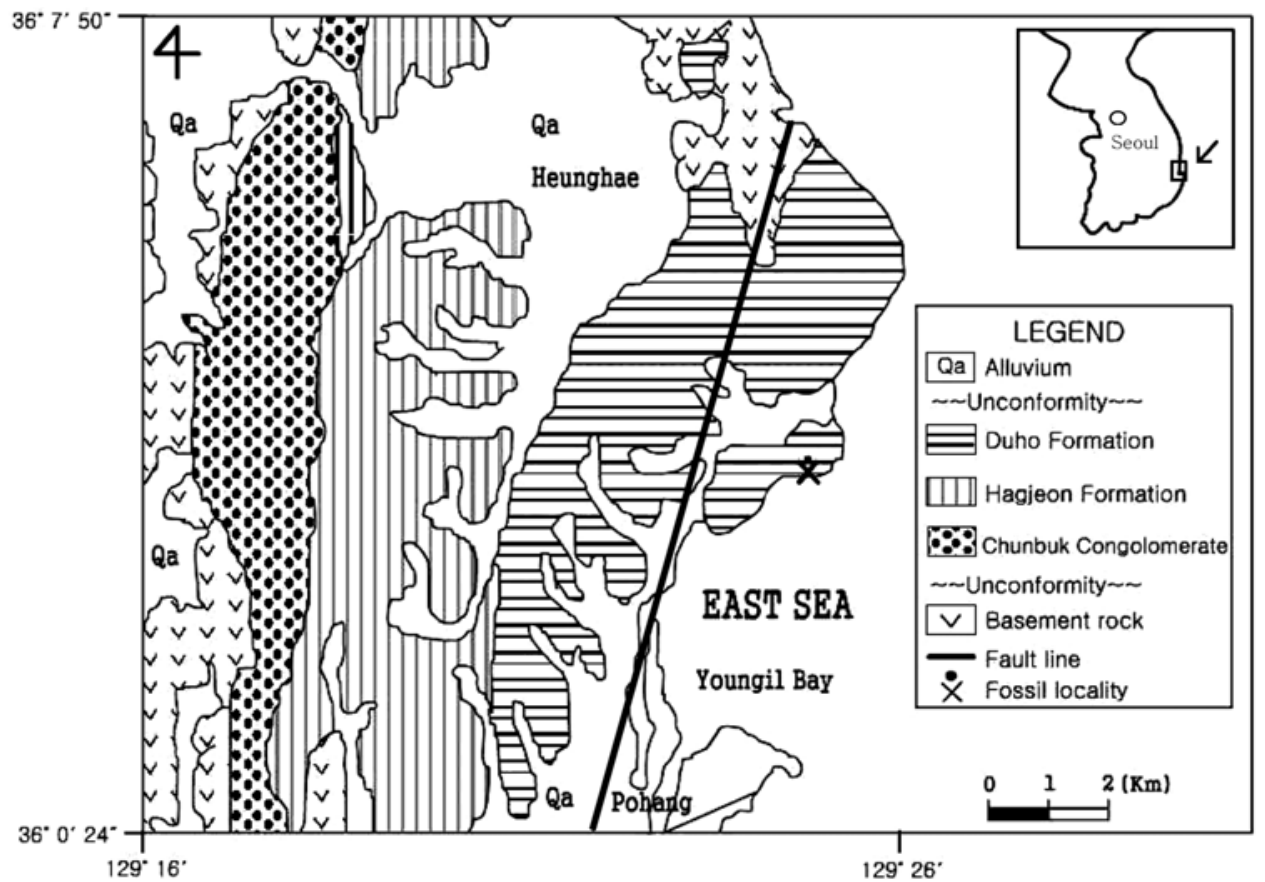

Fig. 1. Geologic map of the Pohang Basin (partly redrawn after Yi and Yun, 1995) and fossil locality.

suggested by some authors, differ from each other, as shown from the correlation of stratigraphic sequence in the Yeonil Group (Yoon, 1998). In this study, the stratigraphic terms suggested by Yun (1986) are used. According to Yun (1986), the Yeonil Group is divided into the Chunbuk conglomerate, Hagjeon, and Duho Formation in ascending order. The fossil locality is shown in Fig. 1. The Duho Formation is widely distributed around Pohang City and consists of mainly dark grey mudstones which are colored whitish brown, when weathered. The mudstones commonly include plant and invertebrate fossils and rarely bear calcareous concretions arranged parallel to the bedding planes. The geological age of the Yeonil Group based on the fossil plants and faunas and microfossils is considered to be Middle Miocene (e.g., Tateiwa, 1924; Kanehara, 1936; Huzioka, 1972; Yoon, 1975; Yun, 1981; Chun et al., 1983).

\section{Material and Method}

Twelve seminiferous scales were obtained from a locality of the Duho Formation distributed along the northern beach of Pohang-City, Kyeongbuk Province. These scales are preserved as impressions on mudstone at a locality where fossil plants and marine faunas are abundant, but no winged seeds were preserved. Seminiferous scales of Pinaceae have been found in the most cases as single detached seminiferous scales or winged seeds and rarely as winged seeds attached to a seminiferous scales. In this study, the seminiferous scales only were examined and compared with fossil and extant species of Pseudolarix. The specimens examined in this study will be kept at the Department of Earth Science, Kongju National University.

\section{Results}

Among 12 seminiferous scales collected from the Duho Formation of the Yeonil Group, 3 species were identified as Pseudolarix japonica, P sp. A and P. sp. B (Fig. 2). 


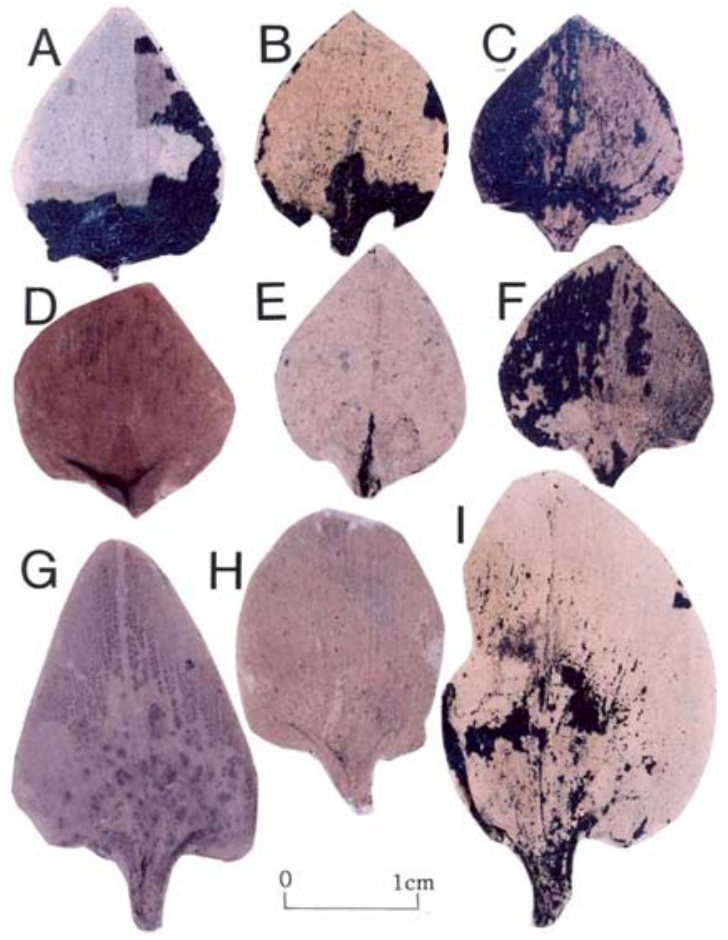

Fig. 2. A-F, H. Pseudolarix sp. A. G. Pseudolarix japonica. I. Pseudolarix sp. B.

\section{Systematic Description}

\author{
Class Gymnospermae \\ Family Pinaceae \\ Pseudolarix Gordon, 1858 \\ Pseudolarix japonica Tanai and Onoe
}

Fig. 2. G

1961 Pseudolarix japonica Tanai and Onoe, p. 17, pl. 1, fig. 5 (cone scale)

\section{Material: KU-CPP-980032}

Description: Seminiferous scale is spate-like in shape, small in size, $2.5 \mathrm{~cm}$ in length and $1.9 \mathrm{~cm}$ in width near the base, roundly obtuse at apex, slightly cordate at base, stalk short and stout, $5 \mathrm{~mm}$ long and $2 \mathrm{~mm}$ wide. No bract scales and seeds have been found.

Occurrence: This species is uncommonly occurred from the Duho Formation.

Remarks: Pseudolarix japonica was originally described by Tanai and Onoe (1961) from the Middle Miocene to Pliocene Onbara Formation of NingyoToge area, Japan based on the single cone scale. Although the present specimen is somewhat smaller in size than the original specimen, it is nearly identical to Pseudolarix japonica Tanai and Onoe.

Miki (1957) reviewed Pseudolarix kaempferi Gordon described by several authors from the Tertiary deposits of Japan. According to Tanai (1961), Miki's Pseudolarix kaempferi is conspecific to Pseudolarix japonica Tanai and Onoe.

Pseudolarix japonica described by Li and Yang (1984) from the Miocene Qiuligou flora in Dunhua County Jilin Province is closely similar to the present species in size and shape.

Gooch (1992) originally described two species of Pseudolarix wehrii and P. arnoldi from the Tertiary deposits of Washington. P. japonica is somewhat similar in seminiferous shape to Pseudolarix wehrii. According to Gooch (1992), Pseudolarix wehrii is conspecific to $P$. americana described as nomen nudum by Arnold (1955) from the Princeton Coal Field of British Columbia.

\section{Pseudolarix sp. A}

Fig. 2. A-F, H

Material: KU-CPP-20041385 (A), 20041362 (B), 20030908 (C), 980033 (D), 20031069 (E), 20030909 (F)

Description: Six seminiferous scales obtained are ovate in shape, the largest one is $1.9 \mathrm{~cm}$ in length and $1.4 \mathrm{~cm}$ in width, typically $1.5-1.7 \mathrm{~cm}$ in length and $1.3-1.5 \mathrm{~cm}$ in width, obtuse at apex, slightly cordate at base. Bract scales are mostly not preserved, but Fig. 2D shows upper part of bract scale partly preserved, but its size and shape is unknown. The preserved bract scale is deltoid in shape, $5 \mathrm{~mm}$ in length and 3 $\mathrm{mm}$ in width. Stalk is short and stout, expanded distally, $4 \mathrm{~mm}$ long and $2 \mathrm{~mm}$ wide. No seeds have been found.

Occurrence: This species is commonly occurred from the Duho Formation.

Remarks: Pseudolarix sp. A is represented by ovate 
seminiferous scales. Only one bract scale bearing specimen is obtained. Pseudolarix sp. A differs sufficiently from Pseudolarix japonica described in the Middle Miocene floras of Japan (Tanai, 1961) in ovate seminiferous scale with an obtuse apex. Although its foliages and seeds were not known, Pseudolarix sp. A is probably new.

Pseudolarix sp. A is somewhat similar in shape of bract scale to $P$. japonica originally described by Tanai and Onoe (1961) from the Mio-Pliocene flora of Japan, but the latter is much larger in size than those of $P$. sp. A and have a spate-like scales with a roundly obtuse apex.

The present seminiferous scales are more or less close to those of Keteleeria dividiana and K. robusta described by Miki (1957) from the Tertiary deposits of Japan. But, the latter two species differ from Pseudolarix sp. A by their bract scale with a tridentate apex.

\section{Pseudolarix sp. B}

Fig. 2. I

Material: KU-CPP-20030039

Description: Seminiferous scale is broad ovate in shape, $2.8 \mathrm{~cm}$ in length and $2 \mathrm{~cm}$ in width, rounded at apex, slightly cordate at base. Stalk is short and stout, $5 \mathrm{~mm}$ in length and $3 \mathrm{~mm}$ in width. No bract scales and seeds have been found.

Occurrence: Only one specimen occurred from the Duho Formation.

Remarks: Pseudolarix sp. B is characterized by its large-sized and broad ovate seminiferous scale with a rounded apex. Due to lack of details of bract scales and seeds, it is difficult to identify at specific level. Accordingly, the present specimen was tentatively assigned to the Pseudolarix sp. B until more information about this type of seminiferous scale is found.

Pseudolarix sp. B clearly differs in size and shape from $P$. japonica and $P$. sp. A described in this paper.

\section{Discussion}

Since Huzioka (1972) reviewed the Korean
Neogene floras described by previous authors (e.g. Kryshtofovich, 1921; Huzioka, 1943, 1972; Tanai, 1952), studies of Korean Neogene floras have been remarkably not progressed for last four decades. In addition to above contributions, a few studies for the plant fossils were made by Lee (1975), Chun (1982), Ablaev et al. (1993), Lim et al. (1994), Kim and Choi (2008), and Kim (2005, 2008, 2009a, b).

According to Huzioka (1972), about 140 species of fossil plants are known from the Korean Miocene floras. Among them, Pinaceae remains are very rare and consist of 4 genera and 6 species such as Picea kaneharai, $P$. ugoana, Keteleeria ezoana, Pinus miocenica, Pinus sp., and Pseudotsuga tanaii. Chun (1982) reported 41 genera and 64 species (including Keteleeria ezoana and Pinus sp.) from the Pohang Basin.

Ablaev et al. (1993) described 32 genera and 48 species of plant fossils from the Miocene Gogeonwon flora in the Hamgyeongbug-do. Among them, the family Pinaceae consists of Pinus sp. and Keteleeria ezoana. Lim et al. (1994) added 5 species of Pinus from the Tertiary deposits of North Korea.

As mentioned above, despite the large number of fossil plants were found from the Neogene strata of Korea, the fossil records of Pinaceae are generally poorly documented. As shown in Table 1, 15 species of Pinaceae including the present study have been identified from the Tertiary floras of Korea. These fossil species are represented by seeds, foliages, cones, and seminiferous scales.

The genus Pseudolarix is monotypic in the family Pinaceae and includes both extant and fossil species. As mentioned by Manchester et al. (2009), the extant Pseudolarix is restricted in modern distribution to central and southeastern China, with only one species of Pseudolarix amabilis (N. Nelson) Rehder, living at 100-1500 $\mathrm{m}$ in elevation (Fu et al., 1999). This species is deciduous tree and commonly known as Golden Larch, and sometimes known under an old scientific name Pseudolarix kaempferi Gordon. However, the fossil records of Pseudolarix show a wide geographic distribution in Asia, Europe and North America of the Northern Hemisphere. 
Table 1. Distribution of Pinaceae species in the Korean Peninsula (Huzioka, 1972; Chun, 1982; Ablaev et al., 1993; Lim et al., 1994; *this study)

\begin{tabular}{|c|c|c|c|c|c|c|}
\hline Flora & Kogeonweon & Hamjingdong & Yongdong & Tongcheon & Changgi & Yeonil \\
\hline Picea kanehara & & 0 & & & O & \\
\hline P. ugoana & & 0 & 0 & & & \\
\hline Pinus miocenica & & & & & & $\bigcirc$ \\
\hline P. sp. & 0 & & & 0 & & 0 \\
\hline P. sp. 1 & & & & & & \\
\hline P. sp. 2 & & & & & & \\
\hline P. sp. 3 & & & & & & \\
\hline P. sp. 4 & & & & & & \\
\hline P. sp. 5 & & & & & & \\
\hline Keteleeria ezoana & 0 & & & & & 0 \\
\hline$K . \mathrm{sp}$. & & & & & & 0 \\
\hline Pseudotsuga ezoana & 0 & & & & 0 & \\
\hline Pseudolarix japonica* & & & & & & 0 \\
\hline$P$. sp. A* & & & & & & 0 \\
\hline P. sp. $\mathrm{B}^{*}$ & & & & & & 0 \\
\hline
\end{tabular}

The oldest record of Pseudolarix is documented in the Cretaceous of Asia and North America (Manchester et al., 2009). The first record of Paleogene Pseudolarix was known in the Middle Eocene of North America (Gooch, 1992) and followed by Oligocene deposits of Asia, Europe and North America (Brown, 1940; Arnold, 1955; Kryshtofovich, 1956; Lehmann et al., 1978; LePage and Basinger, 1995). Pseudolarix was also documented from the Early Miocene to Pliocene in the Northern Hemisphere (Tanai, 1961; Tanai and Onoe, 1961; Tao et al., 2000; Martinetto, 2001; Teodoridis, 2003). Such paleobotanical data indicate that Pseudolarix was once widespread in the Northern Hemisphere that is now endemic to eastern Asia as well as Ginkgo and Metasequoia (Manchester et al., 2009).

Comparing with a world-wide geographical distribution of Pseudolarix in the Northern Hemisphere during the Tertiary age, its diversity of species in fossil records is not so high. It is a striking contrast to a world-wide distribution. For example, only two species of Pseudolarix have been known in the Tertiary floras of East and Central Asia. One is Pseudolarix japonica which is commonly documented in the Miocene floras of Japan and China (Tanai, 1961; Li and Yang, 1984), and the other species is $P$. fossils from the Oligocene flora of central Asia (Kryshtofovich, 1956). Pseudolarix japonica extends to Pliocene in Japan (Tanai, 1961).

As mentioned above, the presence of common species between Korea, Japan, and China during the Miocene Period indicates that there were some interchanges among these regions, even though there were topographic or oceanic barriers between them. Pseudolarix might have flourished under the similar climate as well as Albizia Miokalkora and Metasequoia occidentalis that are now endemic genera to eastern Asia (Kim, 2005; Kim and Choi, 2008; Kim, 2009b).

According to Manchester et al. (2009), Pseudolarix became extinct in North America by the middle to late Early Miocene, and in Europe after the Pliocene. Similarly it is considered that Pseudolarix became extinct together with Albizia, Ginkgo and Metasequoia in Korea after Miocene.

\section{Acknowledgments}

I would like to express my sincere thanks to Professor Jeong-Yul Kim (Korea National University of Education) and Seong-Joo Lee (Kyungpook National University) for their critical reading of the manuscript and valuable suggestions. 


\section{References}

Ablaev, A.G., Sin, E.U., Vassiliev, I.G., and Lu, Z.M., 1993, Miocene of the North Korea and the South Primorye (beds with Engelhardia). Vladivostok, Feb Ran, USSR, 140 p. (in Russian with English abstract)

Arnold, C.A., 1955, Tertiary conifers from coal field of British Columbia. Contributions from the Museum of Paleontology, University of Mishigan, USA, 12, 245-258.

Brown, R.W., 1940, New species and changes of name in some American fossil flora. Journal of the Washington Academy of Science, 30, 344-356.

Chun, H.Y., 1982, Plant fossils from the Tertiary Pohang sedimentary basin, Korea. Research Report, Korea Institute of Energy and Resources, 14, 7-23. (in Korean)

Chun, H.Y., Lee, S.H., Bong, P.Y., and Baek, I.S., 1983, A paleontological study of the Pohang basin (North of the Hyongsan fault). Synthetic Research for Geology of Korea. Korea Institute of Energy and Resources, 7-29. (in Korean English abstract)

Chung, C.H. and Choi, D.K., 1993, Paleoclimate implications of palynoflora from the Yeonil Group (Miocene), Pohang area, Korea. Journal of the Paleontological Society of Korea, 9, 143-154. (in Korean with English abstract)

Fu, L., Ki, N., and Robert, R.M., 1999, In Wu, C.Y. and Raven, PH. (eds.), Flora of China. Vol. 4, Pinaceae. Beijing Science Press, China; ST. Louis: Missouri Botanical Garden Press, USA, 11-52.

Gooch, N.L., 1992, Two new species of Pseudolarix Gordon (Pinaceae) from the Middle Eocene of the Pacific Northwest. Paleobios, 14, 13-19.

Huzioka, K., 1943, On some fossil involucre of Ostrya and Carpinus from the Miocene deposits of Hokkaido and Tyosen. Journal of the Geological Society of Japan, 50, 317-325, pl. 14.

Huzioka, K., 1972, The Tertiary floras of Korea. Journal of Mining College, Akita University, Japan, Series A, 5, 1-83.

Jeong, E.K., Kim, K.S., Kim, J.H., and Suzuki, M., 2003, Comparison of Korean and Japanese Tertiary fossil wood floras with special references to the genus Wataria. Geosciences Journal, 7, 157-161.

Jeong, E.K., Kim, K.S., Kim, J.H., and Suzuki, M., 2004, Fossil woods from Janggi Group (Early Miocene) in Pohang basin, Korea. Journal of Plant Research, 117, 183-189.

Kanehara, K., 1936, On the geological study of the northern part of Yeonil district, Kyeongsangbug-do, Korea (in Japanese). Journal of the Geological Society of Japan, 43, 73-103.

Kim, B.K., 1965, The stratigraphic and palaontologic studies on the Tertiary (Miocene) of the Pohang area, Korea. Seoul National University of Journal, Science and Technology Series, 15, 32-121.
Kim, B.K., 1987, Cenozoic Erathem. In Lee, D.S. (ed.), Geology of Korea. Geological Society of Korea, Kyohak-sa, Seoul, Korea, 202-221.

Kim, B.K. and Yoon, S., 1978, Some molluscan fossils from the Upper most part of the Neogene deposits of the Pohang Basin, Korea. Journal of the Geological Society of Korea, 14, 1-12.

Kim, J.H., 1997, Bibliography of Korean Paleobotany, 1887-1996. Report of Science Education, Kongju National University, Korea, 28, 147-173.

Kim, J.H., 2005, Fossil Albizia Legume (Mimosaceae) from the Miocene Duho Formation of the Yeonil Group in the Pohang area, Korea. Journal of the Korean Earth Science Society, 26, 166-171.

Kim, J.H. and Choi, S.G., 2008, Discussion on the Metasequoia fossils from the Keumkwandong Formation of the Janggi Group, Korea. Journal of the Korean Earth Science Society, 29, 319-327.

Kim, J.H., 2008, A new species of Acer samaras from the Miocene Yeonil Group in the Pohang Basin, Korea. Geosciences Journal, 12, 331-336.

Kim, J.H., 2009a, Species diversity and leaf form of ginkgoaleans from the Mesozoic and Cenozoic strata in Korea. Journal of the Korean Earth Science Society, 30, $1-9$.

Kim, J.H., 2009b, Albizia fruit fossils from the Miocene Duho Formation of Yeonil Group in the Pohang basin, Korea. Journal of the Korean Earth Science Society, 30, $10-18$.

Kryshtofovich, A.N., 1921, Contribution to the Tertiary flora of eastern Asia. To the Tertiary flora of Chang-gi in Korea. Records of Geological Committee of Russian Far East, USSR, 18, 1-14. (in Russian with English abstract)

Kryshtofovich, A.N., 1956, Oligocene flora of Mt. Aschutas in Kazakhstan. Paleobotanica. 1, 1-179. (in Russian)

Lee, S.J., Choi, D.K., Lee, J.D., Yun, H., Lee, Y.N., (eds.), 2004, Korean Paleobios. Paleontological Society of Korea, Special. Publication, 7, 458 p. (in Korean and English)

Lee, H.Y., 1987, Paleobios of Korea. Mineumsa, Seoul, Korea, 434 p. (in Korean)

Lee, W.J., 1975, Discovery of the Miocene Kalopanax leaf from the Geumkwangdong Formation, southeastern Korea. University Journal of Busan National University, Korea, 20, 47-52.

Lee, Y.D., Lee, J.Y., and Lee, Y.G., 1988, A study on the Neogene deposits in the Pohang basin, Korea: With emphasis on sedimentological, palaeontological and mineralogical studies. Journal of the Geological Society of Korea. 24, 16-30. (in Korean with English abstract)

Lee, Y.G., 1986, Micropaleontological study of Neogene strata of southeastern Korea and adjacent sea floor. 
Journal of the Paleontological Society of Korea. 2, 137154

Lehmann, V.U., Thiedig, F., and Harland, W.B., 1978, Spitzbergen im Tertiär. Polarlorschung, 48, 120-138.

LePage, B.A. and Basinger, J.F., 1995, Evolutionary history of the genus Pseudolarix. International Journal of Plant Sciences, 156, 910-950.

Li, H.M. and Yang, G.Y., 1984, Miocene Qiuligou flora in Dunhua County Jilin Province, China. Acta Palaeontologica Sinica, 23, 204-214, pls. 1-3. (in Chinese with English abstract)

Lim, G.H., Chang, C.B., Kwon, J.L., Lee, H.W., Lee, H.S., Kim, C.G., and Park, J.N., 1994, Fossils of Korea. Science and Technology Publishing, Pyeongyang, Korea, 223 p., pls. 96. (in Korean)

Martinetto, E.M., 2001, Studies on some exotic elements of the Pliocene floras of Italy. Palaeontographica Abteilung B, 259, 149-166.

Manchester, S.R., Chen, Z.D., Lu, A.M., and Uemura, M., 2009, Eastern Asian endemic seed plant genera and their paleogeographic history throughout the Northern Hemisphere. Journal of Systematics and Evolution, 47, $1-41$.

Miki, S., 1957, Pinaceae of Japan, with special reference to its remains. Journal of the Institute of Polytechnics, Osaka City University, Japan, Series D, 8, 221-272, pls. $1-10$.

Tanai, T., 1952, Notes a propose de quelques plantes fossils dans le groupe d'ennichi (Yongil) du Corée Méridionale. Transactions and Proceedings of Palaeontological Society of Japan, New Series, 8, 231-236, pl. 22.

Tanai, T., 1961, Neogene floral change in Japan. Journal of Faculty of Science, Hokkaido University, Japan, Series IV, 2, 119-398, pls. 1-32.

Tanai, T., 1983, Revisions of Tertiary Acer from East Asia. Journal of Faculty of Science, Hokkaido University, Japan, Series IV, 20, 291-390.

Tanai, T. and Onoe, T., 1961, A Mio-Pleiocene flora from the Ningyo-toge area on the border between Tottori and Okayama Prefectures, Japan. Report of Geological Survey of Japan, 187, 1-63, pls. 1-18.

Tao, J.R., Zhou, Z.K., and Liu, Y.S., 2000, The evolution of the Late Cretaceous-Cenozoic floras in China. Science Press, Beijing, China, 282 p.

Tateiwa, I., 1924, Tertiary plants from Ennichi and Choki, N. Keisho-do. Journal of Chosen National History and Society, 1, 1-36. (in Japanese)

Tateiwa, I., 1976, The Korea-Japanese geotectonic zone. New interpretations on the geotectonic development of the far East continental territories and the insular arcs of Japan, with special reference to the history of geological research in Korea. Tokyo University Press, Tokyo, Japan, 654 p. (in Japanese)
Teodoridis, V., 2003, Tertiary flora and vegetation of the locality Z'hor near éatec (Most Basin, Czech Republic). Bulletin of Geosciences, 78, 261-276.

Um, S.H., Lee, D.W., and Bak, B.S., 1964, Geological map of Pohang sheet (1:50000) and text. 1-21 (in korean part), 1-10. (in English part)

Yoon, S., 1975, Geology and paleontology of the Tertiary Pohang district, Korea, pt 1 . Geology. Journal of the Geological Society of Korea, 11, 184-214.

Yoon, S., 1976, Geological and paleontological study of the Tertiary deposits of the Janggi-Eoil district of Korea. No. 1, Stratigraphy and geologic age of the Songjeon Formation. Journal of Busan National University, 21 (Natural Science Series), 11-19.

Yoon, S., 1976a, Geological and paleontological study of the Tertiary deposits of Korea. pt. 2. Paleontology (Mollusca), No. 1, systematic description of bivalvia. Journal of the Geological Society of Korea, 12, 1-22.

Yoon, S., 1976b, Geological and paleontological study of the Tertiary deposits of Korea. pt. 2, Paleontology (Mollusca), No. 2, systematic description of Scaphopoda and gastropoda with description of fossil localities. Journal of the Geological Society of Korea, 12, 63-78.

Yoon, S., 1982, Tertiary stratigraphy of the Eoil basin, Korea. Journal of the Geological Society of Korea, 18, 173-180.

Yoon, S., 1992, Geology of the Tertiary Yangnam and Pohang basins, Korea. Bulletin of the Mizunami Fossil Museum, Japan, 19, 13-31.

Yoon, S., 1998, Cenozoic Erathem. In Lee, J.H., Won, J.K., Kim, J.H., and Lee, C.J. (eds), 1998, Geology of Korea. Sigma Press, Seoul, Korea, 274-321. (in Korean)

Yoon, S. and Yun, H.S., 2001, Tertiary sedimentary basin and paleontology of Korea. Guide book of 2001, Palaeontological Society of Korea, 37 p. (in Korean)

Yoon, S. and Rhee, S.H., 1982, Discovery of Vicarya from the Tertiary Pohang Basin, Korea. Journal of the Geological Society of Korea, 18, 49-52.

Yun, H., 1981, Dinoflagellates from the Pohang basin, Korea. Report of Geoscience and Mining Resources, 11, 5-18.

Yun, H., 1986, Emended stratigraphy of the Miocene Formation in the Pohang basin, part 1. Journal of the Palaeontological Society of Korea, 2, 54-69.

Yun, H., 1994, Emended stratigraphy of the Miocene Formations in the Pohang basin, Part II: South of the Hyongsan fault. Journal of the Palaeontological Society of Korea, 10, 99-116.

Manuscript received: July 9, 2009 Revised manuscript received: August 4, 2009 Manuscript accepted: August 10, 2009 